\title{
Role of the Toll-like receptor 3 signaling pathway in the neuroprotective effect of sevoflurane pre-conditioning during cardiopulmonary bypass in rats
}

\author{
JIN ZHOU, NAN ZHOU, XIAO-NING WU, HUI-JUAN CAO, YING-JIE SUN, \\ TIE-ZHENG ZHANG, KE-YAN CHEN and DONG-MEI YU
}

Department of Anaesthesiology, General Hospital of Shenyang Military Region, Shenyang, Liaoning 110015, P.R. China

Received September 28, 2014; Accepted June 23, 2015

DOI: $10.3892 / \mathrm{mmr} .2015 .4420$

\begin{abstract}
The aim of the present study was to explore the roles and possible molecular mechanism of the alleviating effect of sevoflurane pre-treatment on the extracorporeal circulation and to investigate the possible involvement of the Toll-like receptor (TLR3) signaling pathway. A total of 64 male Sprague Dawley rats were randomly divided into three groups: The sham operation group ( $\mathrm{H}$ group; $\mathrm{n}=8$ ), cardiopulmonary bypass (CPB) group (C group; $\mathrm{n}=24$ ) and sevoflurane pre-conditioning group ( $\mathrm{S}$ group; $\mathrm{n}=32$ ). The $\mathrm{C}$ group was subjected to tracheal intubation and mechanical ventilation, vessel puncture and catheter placement in the right femoral artery and right internal jugular vein, while no CPB was performed in the $\mathrm{H}$ group. The $\mathrm{S}$ group was pre-treated with $2.4 \%$ sevoflurane for $1 \mathrm{~h}$ prior to establishing the CPB model. The CPB in the C and $\mathrm{S}$ groups was performed for $1 \mathrm{~h}$. Blood of the rats was analyzed and clinical parameters were detected prior to, during and at various time-points after CPB. In addition, eight rats from the $\mathrm{C}$ and $\mathrm{S}$ groups each were sacrificed at these time-points and brain tissue samples were analyzed. The levels of the brain damage-specific protein S100- $\beta$ as well as IL-6 and IFN- $\beta$ in the serum were detected by ELISA; furthermore, the expression levels of TLR3 and TIR-domain-containing adapter-inducing interferon- $\beta$ (TRIF) in the left hippocampus were assessed by ELISA and/or western blot analysis. The right hippocampus was assessed for neuronal apoptosis by terminal deoxynucleotidyl transferase dUTP nick end labeling assay. The mean arterial pressure, heart rate and hematocrit were significantly decreased following $\mathrm{CPB}(\mathrm{P}<0.05)$, while
\end{abstract}

Correspondence to: Dr Tie-Zheng Zhang or Dr Hui-Juan Cao, Department of Anaesthesiology, General Hospital of Shenyang Military Region, 83 Wenhua Street, Shenyang, Liaoning 110015, P.R. China

E-mail: tzzhang@hotmail.com

E-mail: caohuijuan12@sina.com

Key words: Toll-like receptor 3, sevoflurane, cardiopulmonary bypass, encephalic protection, pre-conditioning there was no significant changes in any other clinical parameters. The serum levels of S100- $\beta$ and IL- 6 in the C group were significantly increased compared with those in the $\mathrm{H}$ group $(\mathrm{P}<0.05)$, which was attenuated by sevoflurane-pre-treatment. Compared with the $\mathrm{H}$ group, the serum levels of IFN- $\beta$ as well as hippocampal protein levels of TLR3 and TRIF were significantly increased in the $\mathrm{C}$ group during and after $\mathrm{CPB}(\mathrm{P}<0.05)$, which was markedly aggravated in the $\mathrm{S}$ group $(\mathrm{P}<0.05)$. The number of apoptotic hippocampal neurons, although being generally low, was significantly increased in the $\mathrm{C}$ group compared with that in the $\mathrm{H}$ group $(\mathrm{P}<0.05)$, while apoptosis was significantly attenuated by sevoflurane-pre-treatment $(\mathrm{P}<0.05)$. The present study therefore concluded that $2.4 \%$ sevoflurane pre-treatment has a protective effect on the rat brain against CPB-induced injury, which may be mediated via the TLR3 signaling pathway through upregulating the expression levels of anti-inflammatory and downregulating pro-inflammatory proteins.

\section{Introduction}

The increasing application of cardiopulmonary bypass (CPB) technology has improved cardiovascular surgeries and significantly increased the survival rate of patients (1). Despite the advantages of CPB, it causes damage to other body parts. Although numerous studies have explored means of reducing the damage of CPB to the body, which led to a significant improvement of the survival rate of patients and a reduction in the incidence of post-operative complications with regard to other organs, the incidence rate of neurological complications has remained relatively constant; for example, the incidence rates of stroke and encephalopathy following CPB are 2-5 and $10-30 \%$, respectively (2). The time of hospitalization of patients following CPB is increased in order to minimize the risk of brain damage and other complications, which leads to the consumption of medical resources and impedes the development of cardiovascular surgery.

The mechanisms of CPB-associated brain injury include cerebralartery embolization, hypoperfusion, cerebral metabolic disorders, inflammatory damage and ischemia/re-perfusion injury $(1,3)$. Among these, inflammatory damage is one of the hotspots of research regarding CPB-induced complications. 
Due to the combination of the patients' immune-associated stress response and damage from surgical equipment and procedures during $\mathrm{CPB}$, activation and release of cytokines as an initiation of the 'inflammatory cascade' leads to systemic inflammatory response syndrome and brain injury. Therefore, mitigating inflammatory damage is an important aspect of cerebral protection during CPB. Bowen et al (4) found that the prevention of the inflammatory reaction not only alleviates inflammation-associated damage but also induces the body's tolerance to ischemic brain injury.

Pradillo et al (5) and Broad et al (6) found that pre-excited Toll-like receptors (TLRs) can not only prevent the inflammatory reaction, but also decrease the area of cerebral ischemic infarct and increase the tolerance to brain injury. The TLR family (7) is a group of recognition receptors of the immune response, which are highly expressed in the central nervous system. TLR3 has a particularly important role within the TLR family (8); first of all, TLR3 is highly expressed in astrocytes; furthermore, there are two immune pathways downstream of the TLR family, including TLR2, 4, 8 and $9(9,10)$, which proceed via the MyD88 pathway, while only TLR3 solely relies on the TIR-domain-containing adapter-inducing interferon- $\beta$ (TRIF)-dependent pathway. Pan et al (11) proved that pre-excited TLR3 can increase the tolerance of brain tissue to ischemic injury and reduce the inflammatory reaction, while promoting the production of anti-inflammatory cytokines and neuroprotective mediators and reducing ischemic brain injury.

The implementation of neuroprotective strategies in the perioperative period can significantly reduce neurological complications after CPB (12-14). Apart from the inhibition of inflammation-induced damage, existing neuroprotective measures include the improvement of CPB devices and surgical techniques as well as ischemic pre-conditioning and the application of protective drugs (15-17). Protective drugs can be divided into classes including narcotics, suppressors of the inflammation reaction and neuroprotective agents. Anesthetic-induced pre-conditioning (APC) (18) and ischemic preconditioning (IPC) (19) have exactly the same mechanism of action, namely the non-noxious stimuli-adaptation/noxious stimuli-tolerance. The neuroprotective effects of sevoflurane amongst anesthetic drugs is one of the current research hotspots $(20,21)$.

As the inhalation of anesthetics is widely used in clinical cardiovascular surgery, the safety of sevoflurane (22) has been confirmed. Studies have confirmed that sevoflurane has a protective effect against damage to the nervous system $(22,23)$. Due to these properties, sevoflurane is suitable for patients undergoing cardiovascular surgery, as it can not only be applied for normal anesthesia but also meets the requirements of patients with poor cardiac function, large hemodynamic fluctuations and high demand for circulation stability, in addition to protecting the nervous system during CPB (24).

Although the protective effects of sevoflurane on the brain have been extensively studied, the exact underlying mechanism has never been fully elucidated. Wang et al (25) confirmed that sevoflurane can upregulate the expression of inflammatory genes at the transcriptional and translational level, repress the expression of adhesion molecules and pro-inflammatory factors, including tumor necrosis factor (TNF)- $\alpha$, interleukin (IL)-1 and IL-6, inhibit the infiltration of neutrophils and macrophages and alleviate inflammatory damage to the nervous system

As these mechanisms are similar to those of the protective effects of TLR3 on the brain, the present study investigated whether sevoflurane protects the brain from CPB-induced inflammatory damage by activating the TLR 3 signaling pathway. For this, a rat model of $\mathrm{CPB}$, which closely resembles clinical CPB in humans (26), was used to study the influence of $2.4 \%$ sevoflurane pre-conditioning on CPB-induced brain injury as well as the involvement of the TLR3 signaling pathway.

\section{Materials and methods}

Experimental devices. The following devices were used: Anesthesia respirator (Draeger, Lübeck, Germany), TCI-III dual-channel target-controlled infusion pump (Wuhan Changfeng Medical Appliance Co.,Ltd, Wuhan, China), patient monitor (Datex-Ohmeda, Helsinki, Finland), NSP5100-type activated clotting time analyzer (Medtronic Inc., Minneapolis, MN, USA), BT00-300 M constant current peristaltic pump (Baoding Longer Precision Pump Co., Ltd., Baoding, China), rat membrane oxygenator (Guangdong Kewei Medical Instrument Co. Ltd., Guangdong, China), 856-type blood gas analyzer (Bayer, Whippany, NJ, USA), high-speed refrigerated centrifuge (Hunan Xiangyi Laboratory Instrument Development Co., Ltd., Hunan, China), small animal ventilator (Jiangxi Province Bentley Anesthesia Breathing Equipment Co., Ltd.) and disposable intravenous trocar $(16,18,20,22,23$ and 24 G; BD Biosciences, Franklin Lakes, NJ, USA).

Drugs and reagents. The following drugs and reagents were used in the present study: Sevoflurane (Shanghai Hengrui Medicine Co., Ltd, Shanghai, China), 10\% chloral hydrate (Qingdao Yulong Algae Co., Ltd., Qingdao, China) 5\% sodium bicarbonate (Jiang Su Runyang Pharmaceutical Co., Ltd., Jiangsu, China), 20\% mannitol (Baxter Healthcare Trading Co, Ltd., Shanghai, China), 6\% hydroxyethyl starch (Beijing Fresenius-Kabi Pharmaceutical Co., Ltd., Beijing, China), heparin sodium (Tianjin Pharmaceutical Group Co., Ltd., Tianjin, China), soda-lime (England Molecular Products Limited Co., Ltd., Harlow, UK), $10 \%$ formalin (Sinopharm Chemical Reagent Co., Ltd., Shanghai, China), Ponceau S (Beijing Solarbio Science \& Technology Co., Ltd., Beijing, China), rat TLR3 (cat. no. 1487-TR-050), TRIF (cat. no. ab101232), IL-6 (cat. no. D6050), interferon (IFN)- $\beta$ (cat. no. 41410-1), S100- $\beta$ (cat. no. DY5578) ELISA kits (R\&D Systems, Inc., Minneapolis, MN, USA), terminal deoxynucleotidyl transferase dUTP nick end labeling (TUNEL) positive test kit (Beijing Zhongshan Golden Bridge Biotechnology Co., Ltd., Beijing, China).

Experimental animals and grouping. A total of 64 adult male Sprague Dawley rats (age, 12 weeks), weighing 350-450 g were provided by the Shenyang Military Region General Hospital Laboratory Animal Center (Shenyang, China; lot no. 20120002). The rats were maintained in a temperature $\left(25^{\circ} \mathrm{C}\right)$ and humidity $(50 \%)$ controlled environment, under a $12 \mathrm{~h}$ light/dark cycle. The rats were sacrificed by cervical dislocation. The animal experiments were approved by the Animal 
Experiments Ethics Committee of the General Hospital of Shenyang Military Region (Shenyang, China). Animals were fasted with free access to water for $12 \mathrm{~h}$ prior to surgery.

The animals were randomly divided into three groups: The sham operation group (H group; $n=8)$, the CPB group ( $\mathrm{C}$ group; $\mathrm{n}=24$ ) and the sevoflurane pre-conditioning group (S group; $n=32$ ).

Model preparation and treatment. Rats were prepared for CPB by intraperitoneal injection with $10 \%$ chloral hydrate (300 mg/kg) for anesthesia. Photopic oral intubation was performed using a $16 \mathrm{G}$ intravenous catheter, and animals were mechanically ventilated with a small animal ventilator (settings: Frequency, 60 beats/min; tidal volume, $3 \mathrm{ml} / \mathrm{kg}$; inspiratory to expiratory ratio, $1: 1.5$ ) connected to a monitor to observe the heart rate, oxygen saturation and rectal temperature of the rats.

Hair was removed at the puncture site, followed by disinfection, skin incision as well as isolation, exposure and puncture of the vascular vein. Left femoral vein catheterization $(23 \mathrm{G})$ was performed to open the fluid path, which was and connected to a micro infusion pump. The left femoral artery was catheterized $(24 \mathrm{G})$ and connected to the monitor for real-time monitoring of blood pressure. The right internal jugular vein was catheterized into the right atrium using a homemade long-short drainage needle (16G) in order to drain blood for CPB. The right femoral artery was catheterized for fixed CPB perfusion. Between the two puncture sites with the drainage tube, a homemade blood storage device, a constant peristaltic pump (Baoding Longer Precision Pump Co., Ltd.), silicone tubing (internal diameter, $4 \mathrm{~mm}$ ) and a rat membrane oxygenator (Guangdong Kewei Medical Instrument Co. Ltd.) were installed to establish the CPB circuit. The left femoral vein was selected as the systemic heparin site in the rats, and heparin sodium $(300 \mathrm{IU} / \mathrm{kg}$ ) was injected when the activated clotting time reached 400-500 sec. Rats were pre-charged without blood to establish the without-blood pre-charge and the non-arrest charge CPB model in rats.

$\mathrm{CPB}$ was then performed using the membrane oxygenator to immediately supply oxygen. The low-flow CPB velocity was $35 \mathrm{ml} / \mathrm{kg} / \mathrm{min}$, which was later increased to $100-120 \mathrm{ml} / \mathrm{kg} / \mathrm{min}$ at full-flow bypass. To prevent the formation of air embolism, 1-2 $\mathrm{ml}$ of blood was retained in the blood storage device whenever possible. The mean arterial pressure (MAP) was maintained at $>60 \mathrm{mmHg}$, the $\mathrm{pH}$ was kept at 7.35-7.45, the partial $\mathrm{CO}_{2}$ pressure $\left(\mathrm{PaCO}_{2}\right)$ was kept at at $35-45 \mathrm{mmHg}$ and hematocrit (Hct) was maintained at $>0.25$. Rats were provided with epinephrine hydrochloride $(2-20 \mu \mathrm{g} / 100 \mathrm{~g}$; Wuhan Grand Pharmaceutical Group Co., Ltd., Wuhan, China) and fluids intraoperatively in order to maintain a stable circulation.

Treatment of experimental groups. In the $\mathrm{H}$ group, intubation and mechanical ventilation was performed in the right femoral artery only and the right internal jugular vein was catheterized without bypass. In the $\mathrm{C}$ group, the $\mathrm{CPB}$ model was established as described above. On the $\mathrm{S}$ group, 2.4\% sevoflurane pre-conditioning was performed for $1 \mathrm{~h}$ prior to establishing the CPB model.

In groups $\mathrm{C}$ and $\mathrm{S}, \mathrm{CPB}$ was performed for $1 \mathrm{~h}$. During sevoflurane pre-conditioning, soda lime was placed under the gauze. For pre-conditioning, a box with two outlet holes was used - one hole to connect to the anesthesia ventilator and the other one to connect to the gas collection of the monitor to real-time monitor the concentration of oxygen and sevoflurane. The temperature inside the box was maintained at $35-37^{\circ} \mathrm{C}$, the sevoflurane concentration was adjusted to $2.4 \%$ and rats were pre-conditioned for $1 \mathrm{~h}$.

Specimen collection and processing. Arterial and venous blood samples were collected at the following time-points: Prior to CPB ( $\left.\mathrm{T}_{0}\right)$, CPB for $30 \mathrm{~min}\left(\mathrm{~T}_{1}\right), \mathrm{CPB}$ for $1 \mathrm{~h}\left(\mathrm{~T}_{2}\right), 1 \mathrm{~h}$ after CPB $\left(\mathrm{T}_{3}\right), 2 \mathrm{~h}$ after CPB $\left(\mathrm{T}_{4}\right)$ and $3 \mathrm{~h}$ after CPB $\left(\mathrm{T}_{5}\right)$. In addition, at $\mathrm{T}_{0}, \mathrm{~T}_{1}, \mathrm{~T}_{3}$ and $\mathrm{T}_{5}$, eight rats from the $\mathrm{S}$ group and $\mathrm{C}$ group were sacrificed and their brain tissue was collected.

Brain tissue. Rats were infused with 250-400 ml saline, and the systemic circulation system was flushed and perfused. The skull was opened, the whole brain was removed, placed on an ice sheet and divided into two halves by a median sagittal line. The hippocampus was isolated from the two halves and then stored at $-80^{\circ} \mathrm{C}$ (left) and in $10 \%$ neutral formalin (right).

Venous blood serum and arterial blood gas. Venous blood samples were collected by centrifugation $(10,000 \mathrm{x} \mathrm{g;} 10 \mathrm{~min})$, and serum was stored in a cryogenic refrigerator $\left(-80^{\circ} \mathrm{C}\right)$. Blood samples from the left femoral artery were subjected to blood gas analysis ( $0.3 \mathrm{ml}$ per run). An equivalent volume of $6 \%$ hydroxyethyl starch was intravenously injected after sampling.

Determination of S100- $\beta, I L-6, I F N-\beta$ in the rat serum by ELISA assay. The serum levels of S100- $\beta, I L-6, I F N-\beta$ were determined according to the manufacturer's instructions of the ELISA kits. The optical density was measured at $450 \mathrm{~nm}$ using a microplate reader (ELX800; Bio-Tek Instruments, Inc., Winooski, VT, USA) and analyzed using Gen5 software (Biotek Instruments, Inc.).

Determination of TLR3 and TRIF in the rat hippocampus by ELISA. The hippocampus was weighed and ground with 10 volumes of phosphate-buffered saline (PBS), followed by centrifugation (10,000 x g, $15 \mathrm{~min}$ ) and collection of the supernatant. The protein levels of TLR3 and TRIF were detected by ELISA according to the manufacturer's instructions.

Western blot analysis of protein levels of TLR3 in the rat hippocampus. After weighing and grinding the hippocampus, radioimmunoprecipitation assay buffer (Beijing Soledad Bao Biological Technology Co., Ltd., Beijing, China) was added (1 ml/100 mg tissue) and then homogenized (IKA T10; IKA ${ }^{\circledR}$-Werke GmbH \& Co. KG, Staufen, Germany) and centrifuged $\left(4^{\circ} \mathrm{C}, 12,000 \mathrm{x} \mathrm{g}, 15 \mathrm{~min}\right)$. The supernatant was collected and protein concentrations were determined using a Bicinchoninic Acid kit (Beijing Soledad Bao Biological Technology Co., Ltd.). Loading buffer was then added to the protein samples. The protein $(80 \mu \mathrm{g})$ was separated by $8 \%$ SDS-PAGE at $100 \mathrm{~V}$ for 10-20 min. The voltage was increased to $200 \mathrm{~V}$ when the indicator entered the separation gel, and electrophoresis was continued for another 30-40 min. The blot was then electrophoretically transferred onto a nitrocellulose membrane and blocked with 5\% non-fat milk in PBS 
Table I. Clinical parameters and blood gas analysis at various time-points.

\begin{tabular}{|c|c|c|c|c|c|c|}
\hline Project & $\mathrm{T}_{0}$ & $\mathrm{~T}_{1}$ & $\mathrm{~T}_{2}$ & $\mathrm{~T}_{3}$ & $\mathrm{~T}_{4}$ & $\mathrm{~T}_{5}$ \\
\hline MAP (mmHg) & $105.81 \pm 11.67$ & $79.46 \pm 7.21^{\mathrm{a}}$ & $73.66 \pm 5.28^{a}$ & $96.54 \pm 6.11$ & $93.25 \pm 8.04$ & $103.74 \pm 8.23$ \\
\hline $\mathrm{HR}(/ \min )$ & $309.70 \pm 13.84$ & $289.49 \pm 12.02^{\mathrm{a}}$ & $290.50 \pm 9.74^{\mathrm{a}}$ & $300.03 \pm 11.34$ & $303.69 \pm 9.86$ & $311.35 \pm 9.24$ \\
\hline $\mathrm{RT}\left({ }^{\circ} \mathrm{C}\right)$ & $36.96 \pm 0.33$ & $34.42 \pm 0.26$ & $35.22 \pm 0.33$ & $36.61 \pm 0.32$ & $36.85 \pm 0.27$ & $36.87 \pm 0.41$ \\
\hline $\mathrm{pH}$ & $7.40 \pm 0.03$ & $7.37 \pm 0.02$ & $7.37 \pm 0.02$ & $7.38 \pm 0.02$ & $7.39 \pm 0.03$ & $7.39 \pm 0.03$ \\
\hline $\mathrm{PaCO}_{2}(\mathrm{mmHg})$ & $38.34 \pm 2.63$ & $39.27 \pm 3.22$ & $39.32 \pm 4.01$ & $40.22 \pm 2.79$ & $39.64 \pm 2.51$ & $40.75 \pm 3.03$ \\
\hline $\mathrm{PaO}_{2}(\mathrm{mmHg})$ & $322.28 \pm 21.35$ & $309.52 \pm 14.39$ & $307.47 \pm 19.38$ & $301.52 \pm 10.83$ & $311.29 \pm 17.85$ & $309.02 \pm 15.63$ \\
\hline $\mathrm{BE}(\mathrm{mmol} / \mathrm{l})$ & $-1.3 \pm 0.53$ & $-2.5 \pm 0.63$ & $-2.3 \pm 0.37$ & $-2.2 \pm 0.45$ & $-1.3 \pm 0.25$ & $-2.5 \pm 0.34$ \\
\hline Hct & $38.68 \pm 3.48$ & $29.83 \pm 2.66^{\mathrm{a}}$ & $30.13 \pm 2.19^{\mathrm{a}}$ & $34.62 \pm 3.07^{\mathrm{a}}$ & $33.24 \pm 2.75^{\mathrm{a}}$ & $32.56 \pm 2.81^{\mathrm{a}}$ \\
\hline $\mathrm{K}^{+}(\mathrm{mmol} / \mathrm{l})$ & $4.27 \pm 0.39$ & $4.30 \pm 0.38$ & $4.25 \pm 0.82$ & $4.17 \pm 0.40$ & $4.31 \pm 0.42$ & $4.33 \pm 0.37$ \\
\hline
\end{tabular}

Values are expressed as the mean \pm standard deviation. ${ }^{\mathrm{a}} \mathrm{P}<0.05$ compared with $\mathrm{T}_{0} . \mathrm{T}_{0}$, prior to $\mathrm{CPB} ; \mathrm{T}_{1}, \mathrm{CPB}$ for $30 \mathrm{~min} ; \mathrm{T}_{2}, \mathrm{CPB}$ for $1 \mathrm{~h} ; \mathrm{T}_{3}$, $1 \mathrm{~h}$ after 1-h $\mathrm{CPB} ; \mathrm{T}_{4}, 2 \mathrm{~h}$ after 1-h CPB; $\mathrm{T}_{5}, 3 \mathrm{~h}$ after 1-h CPB; CPB, cardiopulmonary bypass; MAP, mean arterial pressure, HR, heart rate; RT, rectal temperature; Pa, partial pressure; BE, base excess; Hct, hematocrit.

with Tween 20 (PBST). The membrane was incubated with the rabbit anti-TLR3 polyclonal antibody (1:600 dilution; cat. no. PL031444R; Beijing Biosynthesis Biological Technology Co., Ltd., Beijing, China) and goat polyclonal $\beta$-actin antibody (1:500 dilution; cat. no. ab8229) at $4{ }^{\circ} \mathrm{C}$ overnight, washed with TBST five times and then incubated with the horseradish peroxidase-conjugated goat anti-rabbit IgG secondary antibody (Alexa Fluor ${ }^{\circledR} 488$; cat. no. ab175735; 1:5,000; Beijing Biosynthesis Biological Technology Co., Ltd.). The membrane was visualized using an Enhanced Chemiluminescence kit (Beijing Biosynthesis Biological Technology Co., Ltd.). Images were analyzed using Quantity One version 4.62 software (Bio-Rad Laboratories, Hercules, CA, USA), and expression of the target protein was normalized to $\beta$-actin.

In situ detection of apoptosis of hippocampal neurons by TUNEL assay. Paraffin (Sinopharm Chemical Reagent Co., Ltd.) sections of hippocampal tissue were de-paraffinized and re-hydrated, digested with proteinase $\mathrm{K}$ solution for $15 \mathrm{~min}$ and washed four times with water. Sections were then incubated with $\mathrm{H}_{2} \mathrm{O}_{2}$-PBS buffer at room temperature for $15 \mathrm{~min}$ and washed with PBS three times for $5 \mathrm{~min}$ each. Samples were incubated with PBS containing TUNEL stain (KGI Nanjing Biotechnology Development Co., Ltd., Nanjing, China) for $60 \mathrm{~min}$ and with stop buffer for $30 \mathrm{~min}$, followed by washing with PBS. Sections were incubated with horseradish peroxidase for $30 \mathrm{~min}$, washed with $\mathrm{PBS}$ and then incubated with diaminobenzidine- $\mathrm{H}_{2} \mathrm{O}_{2}$ for $3 \mathrm{~min}$. Following washing with PBS, samples were stained with methyl green for $10 \mathrm{~min}$, and washed with distilled water and n-butanol three times each for, $1 \mathrm{~min}$. Samples were dehydrated with xylene (Sinopharm Chemical Reagent Co., Ltd.) three times, dried and mounted. Normal neuronal nuclei were identified by a blue stain by hematoxylin (Sinopharm Chemical Reagent Co., Ltd.), defining them as negative for apoptosis. Damaged neuronal nuclei were identified by a brown stain, which indicated DNA breakage, defining them as positive for apoptosis. Fixed slices from each group were randomly selected from which five fields of view were randomly selected to capture images at high-power magnification (x400). The average integrated optical density values of damaged neurons were determined with a microscopic image analysis system (BX41; Olympus Corporation, Tokyo, Japan).

Statistical analysis. All statistical analyses were performed using SPSS 19.0 statistical software (International Business Machines, Armonk, NY, USA). Values are expressed as the mean \pm standard deviation. Comparisons between groups were performed using one-way analysis of variance, and comparisons within a group were analyzed with repeated measures analysis of variance. $\mathrm{P}<0.05$ was considered to indicate a statistically significant difference between values.

\section{Results}

Blood gas analysis and clinical parameters during CPB. The MAP, heart rate (HR), Hct, rectal temperature, $\mathrm{pH}$ value, $\mathrm{PaCO}_{2}, \mathrm{PaO}_{2}$, base excess $(\mathrm{BE})$ value and $\mathrm{K}^{+}$at the indicated times in the three groups of rats show no statistically significant differences $(\mathrm{P}>0.05)$. The MAP and HR were significantly decreased during $\mathrm{CPB}$ (compared to $\mathrm{T}_{0} ; \mathrm{P}<0.05$ ), while after $\mathrm{CPB}$, a gradual recovery was shown (compared to $\mathrm{T}_{0} ; \mathrm{P}>0.05$ ). The Hct value was significantly decreased during $\mathrm{CPB}(\mathrm{P}<0.05)$, while the $\mathrm{pH}, \mathrm{Hct}, \mathrm{PaCO}_{2}, \mathrm{PaO}_{2}, \mathrm{BE}$ and $\mathrm{K}^{+}$levels exhibited no statistically significant differences at different time-point within the groups (compared to $\mathrm{T}_{0} ; \mathrm{P}>0.05$ ), Table I.

Sevoflurane-pre-conditioning attenuates $C P B$-induced increases in serum levels of S100- $\beta$ and IL-6. The serum concentration of S100- $\beta$ and IL- 6 in the $C$ group was significantly increased during and after $\mathrm{CPB}$ at $\mathrm{T}_{1}-\mathrm{T}_{5}(\mathrm{P}<0.05)$. Of note, the S100- $\beta$ and IL- 6 concentration in the $S$ group was significantly lower than that in the $\mathrm{C}$ group $(\mathrm{P}<0.05)$ indicating that pre-treatment with sevofluorane attenuated the CPB-induced increases in S100- $\beta$ and IL-6 (Tables II and III; Figs. 1 and 2).

Sevoflurane-pre-conditioning aggravates CPB-induced increases in serum levels of IFN- $\beta$ as well as hippocampal levels of TLR 3 and TRIF. The serum concentration of IFN- $\beta$ as well as hippocampal levels of TLR3 and TRIF in the C group 
Table II. S100- $\beta$ levels in the experimental groups at various time-points.

\begin{tabular}{lcccccc}
\hline Group & $\mathrm{T}_{0}$ & $\mathrm{~T}_{1}$ & $\mathrm{~T}_{2}$ & $\mathrm{~T}_{3}$ & $\mathrm{~T}_{4}$ & $\mathrm{~T}_{5}$ \\
\hline H group & $7.21 \pm 0.76$ & $7.39 \pm 0.80$ & $7.14 \pm 0.78$ & $7.19 \pm 0.80$ & $7.32 \pm 0.79$ & $7.10 \pm 0.79$ \\
C group & $7.58 \pm 0.68$ & $15.79 \pm 1.33^{\mathrm{a}, \mathrm{b}}$ & $15.12 \pm 1.34^{\mathrm{a}, \mathrm{b}}$ & $14.21 \pm 1.32^{\mathrm{a}, \mathrm{b}}$ & $15.21 \pm 1.41^{\mathrm{a}, \mathrm{b}}$ & $15.79 \pm 1.43^{\mathrm{a}, \mathrm{b}}$ \\
S group & $7.19 \pm 0.82$ & $14.28 \pm 1.32^{\mathrm{a}-\mathrm{c}}$ & $13.12 \pm 1.34^{\mathrm{a}-\mathrm{c}}$ & $11.35 \pm 1.43^{\mathrm{a}-\mathrm{c}}$ & $12.12 \pm 1.41^{\mathrm{a}-\mathrm{c}}$ & $13.53 \pm 1.42^{\mathrm{a}-\mathrm{c}}$ \\
\hline
\end{tabular}

Values are expressed as the mean \pm standard deviation. ${ }^{\mathrm{a}} \mathrm{P}<0.05$ compared to $\mathrm{H}$ group; ${ }^{\mathrm{b}} \mathrm{P}<0.05$ compared to $\mathrm{T}_{0}$ group; ${ }^{\mathrm{C}}<0.05$ compared to $\mathrm{H}$ group. $\mathrm{H}$, sham group; $\mathrm{C}, \mathrm{CPB}$ group; $\mathrm{S}$, sevoflurane-pre-conditioned group; $\mathrm{T}_{0}$, prior to $\mathrm{CPB} ; \mathrm{T}_{1}, \mathrm{CPB}$ for $30 \mathrm{~min} ; \mathrm{T}_{2}, \mathrm{CPB}$ for $1 \mathrm{~h} ; \mathrm{T}_{3}, 1 \mathrm{~h}$ after 1-h $\mathrm{CPB} ; \mathrm{T}_{4}, 2 \mathrm{~h}$ after $1-\mathrm{h} \mathrm{CPB} ; \mathrm{T}_{5}, 3 \mathrm{~h}$ after $1-\mathrm{h} \mathrm{CPB} ; \mathrm{CPB}$, cardiopulmonary bypass.

Table III. Serum levels of IL-6 in the experimental groups at various time-points.

\begin{tabular}{lcccccc}
\hline Group & $\mathrm{T}_{0}$ & $\mathrm{~T}_{1}$ & $\mathrm{~T}_{2}$ & $\mathrm{~T}_{3}$ & $\mathrm{~T}_{4}$ & $\mathrm{~T}_{5}$ \\
\hline H group & $9.60 \pm 0.85$ & $9.53 \pm 0.76$ & $9.47 \pm 0.85$ & $9.57 \pm 0.72$ & $9.51 \pm 0.71$ & $9.79 \pm 0.68$ \\
C group & $9.77 \pm 0.61$ & $12.53 \pm 1.07^{\mathrm{a}, \mathrm{b}}$ & $11.99 \pm 1.09^{\mathrm{a}, \mathrm{b}}$ & $11.67 \pm 1.10^{\mathrm{a}, \mathrm{b}}$ & $11.37 \pm 0.99^{\mathrm{a}, \mathrm{b}}$ & $11.76 \pm 1.08^{\mathrm{a}, \mathrm{b}}$ \\
S group & $9.69 \pm 0.80$ & $11.68 \pm 1.20^{\mathrm{a}-\mathrm{c}}$ & $10.06 \pm 1.12^{\mathrm{a}-\mathrm{c}}$ & $10.62 \pm 1.00^{\mathrm{a}-\mathrm{c}}$ & $10.58 \pm 0.91^{\mathrm{a}-\mathrm{c}}$ & $10.16 \pm 0.94^{\mathrm{a}-\mathrm{c}}$ \\
\hline
\end{tabular}

Values are expressed as the mean \pm standard deviation. ${ }^{\mathrm{a}} \mathrm{P}<0.05$ compared to $\mathrm{H}$ group; ${ }^{\mathrm{b}} \mathrm{P}<0.05$ compared to $\mathrm{T}_{0}$ group; ${ }^{\mathrm{C}}<0.05$ compared to $\mathrm{H}$ group. $\mathrm{H}$, sham group; $\mathrm{C}$, CPB group; $\mathrm{S}$, sevoflurane-pre-conditioned group; $\mathrm{T}_{0}$, prior to $\mathrm{CPB} ; \mathrm{T}_{1}, \mathrm{CPB}$ for $30 \mathrm{~min} ; \mathrm{T}_{2}, \mathrm{CPB}$ for $1 \mathrm{~h} ; \mathrm{T}_{3}, 1 \mathrm{~h}$ after 1-h CPB; $\mathrm{T}_{4}, 2 \mathrm{~h}$ after 1-h CPB; $\mathrm{T}_{5}, 3 \mathrm{~h}$ after 1-h CPB; CPB, cardiopulmonary bypass; IL, interleukin.

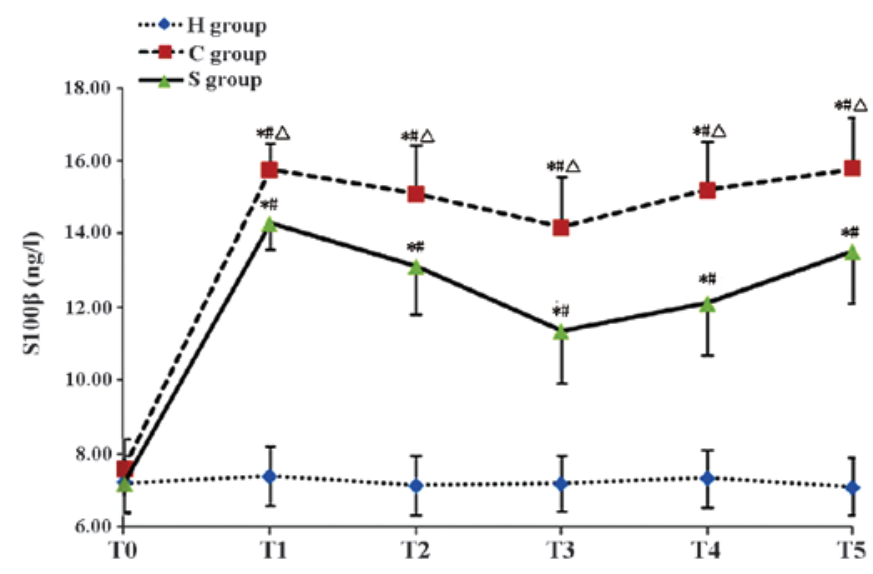

Figure 1. Concentration of S100- $\beta$ in the experimental groups at various time-points. Values are expressed as the mean \pm standard deviation. ${ }^{~} \mathrm{P}<0.05$ compared with $\mathrm{T}_{0}$; ${ }^{*} \mathrm{P}<0.05$ compared to $\mathrm{H}$ group; ${ }^{\Delta} \mathrm{P}<0.05$ compared with $\mathrm{S}$ group. $\mathrm{H}$, sham group; $\mathrm{C}, \mathrm{CPB}$ group; $\mathrm{S}$, sevoflurane-pre-conditioned group; $\mathrm{T}_{0}$, prior to $\mathrm{CPB} ; \mathrm{T}_{1}, \mathrm{CPB}$ for $30 \mathrm{~min} ; \mathrm{T}_{2}, \mathrm{CPB}$ for $1 \mathrm{~h} ; \mathrm{T}_{3}, 1 \mathrm{~h}$ after 1-h CPB; $\mathrm{T}_{4}, 2 \mathrm{~h}$ after 1-h CPB; $\mathrm{T}_{5}, 3 \mathrm{~h}$ after 1-h CPB; CPB, cardiopulmonary bypass.

were significantly increased during and after CPB at $\mathrm{T}_{1}-\mathrm{T}_{5}$ $(\mathrm{P}<0.05)$. Of note, IFN- $\beta$, TLR3 and TRIF levels in the $\mathrm{S}$ group were significantly increased compared with those in the $C$ group $(\mathrm{P}<0.05)$, indicating that pre-treatment with sevofluorane aggravated the CPB-induced increases IFN- $\beta$, TLR3 and TRIF (Tables IV-VI; Figs. 3-7)

Sevoflurane-pre-conditioning reduces $C P B$-induced apoptosis of hippocampal neurons. The results of the TUNEL assay showed that the number of apoptotic hippocampal neuron cells was extremely low. However, in the $\mathrm{C}$ and $\mathrm{S}$ groups, the number

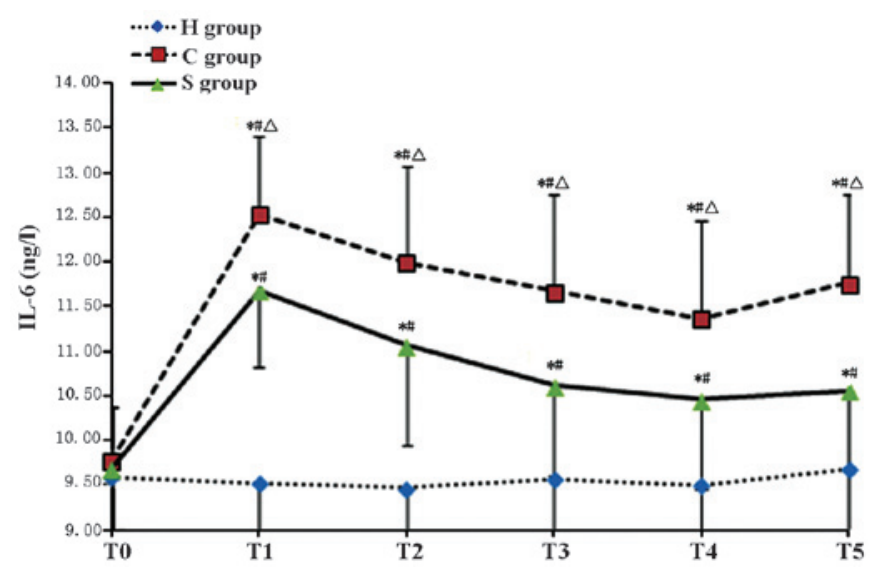

Figure 2. Serum levels of IL-6 in the experimental groups at various time-points. Values are expressed as the mean \pm standard deviation. ${ }^{\#} \mathrm{P}<0.05$ compared with $\mathrm{T}_{0} ;{ }^{*} \mathrm{P}<0.05$ compared to $\mathrm{H}$ group; ${ }^{\circ} \mathrm{P}<0.05$ compared with $\mathrm{H}$ group. $\mathrm{H}$, sham group; $\mathrm{C}, \mathrm{CPB}$ group; $\mathrm{S}$, sevoflurane-pre-conditioned group; $\mathrm{T}_{0}$, prior to CPB; $\mathrm{T}_{1}, \mathrm{CPB}$ for $30 \mathrm{~min}$; $\mathrm{T}_{2}, \mathrm{CPB}$ for $1 \mathrm{~h} ; \mathrm{T}_{3}, 1 \mathrm{~h}$ after 1 -h CPB; $\mathrm{T}_{4}, 2 \mathrm{~h}$ after 1 - $\mathrm{h} \mathrm{CPB} ; \mathrm{T}_{5}, 3 \mathrm{~h}$ after 1 - $\mathrm{h} \mathrm{CPB}$; CPB, cardiopulmonary bypass; IL, interleukin.

of apoptotic hippocampal neurons was significantly higher than that in the $\mathrm{H}$ group $(\mathrm{P}<0.05)$. Of note, the number of apoptotic cells was significantly reduced in the $\mathrm{S}$ group as compared to that in the $\mathrm{C}$ group, indicating that sevoflurane had a protective effect on hippocampal neurons during and following CPB (Figs. 8 and 9).

\section{Discussion}

Impact of sevoflurane pre-conditioning on brain injury during $C P B$. Sevoflurane is commonly used as an anesthetic in the 
Table IV. Serum levels of IFN- $\beta$ in the experimental groups at various time-points.

\begin{tabular}{lcccccc}
\hline Group & \multicolumn{1}{c}{$\mathrm{T}_{0}$} & \multicolumn{1}{c}{$\mathrm{T}_{1}$} & \multicolumn{1}{c}{$\mathrm{T}_{2}$} & \multicolumn{1}{c}{$\mathrm{T}_{3}$} & \multicolumn{1}{c}{$\mathrm{T}_{4}$} & \multicolumn{1}{c}{$\mathrm{T}_{5}$} \\
\hline H group & $156.55 \pm 13.82$ & $160.02 \pm 13.68$ & $156.45 \pm 14.59$ & $160.02 \pm 13.98$ & $152.20 \pm 14.87$ & $157.59 \pm 13.59$ \\
C group & $156.41 \pm 14.06$ & $221.26 \pm 18.66^{\mathrm{a}, \mathrm{b}}$ & $202.29 \pm 17.29^{\mathrm{a}, \mathrm{b}}$ & $188.79 \pm 16.84^{\mathrm{a}, \mathrm{b}}$ & $198.69 \pm 17.13^{\mathrm{a}, \mathrm{b}}$ & $190.95 \pm 16.39^{\mathrm{a}, \mathrm{b}}$ \\
S group & $160.71 \pm 14.03$ & $252.26 \pm 19.74^{\mathrm{a}-\mathrm{c}}$ & $248.66 \pm 18.38^{\mathrm{a}-\mathrm{c}}$ & $232.45 \pm 18.06^{\mathrm{a}-\mathrm{c}}$ & $235.98 \pm 18.45^{\mathrm{a}-\mathrm{c}}$ & $236.55 \pm 18.58^{\mathrm{a}-\mathrm{c}}$ \\
\hline
\end{tabular}

Values are expressed as the mean \pm standard deviation. ${ }^{\mathrm{a}} \mathrm{P}<0.05$, compared with the $\mathrm{H}$ group; ${ }^{\mathrm{b}} \mathrm{P}<0.05$, compared with the $\mathrm{T}_{0}$ group; ${ }^{\mathrm{c}} \mathrm{P}<0.05$, compared with the $\mathrm{C}$ group. $\mathrm{H}$, sham group; $\mathrm{C}$, $\mathrm{CPB}$ group; $\mathrm{S}$, sevoflurane-pre-conditioned group; $\mathrm{T}_{0}$, prior to $\mathrm{CPB} ; \mathrm{T}_{1}, \mathrm{CPB}$ for 30 min; $\mathrm{T}_{2}$, $\mathrm{CPB}$ for $1 \mathrm{~h} ; \mathrm{T}_{3}, 1 \mathrm{~h}$ after 1-h CPB; $\mathrm{T}_{4}, 2 \mathrm{~h}$ after 1-h CPB; $\mathrm{T}_{5}, 3 \mathrm{~h}$ after 1-h CPB; CPB, cardiopulmonary bypass; IFN, interferon.

Table V. TLR3 expression levels rat hippocampi in the experimental groups at various time-points.

\begin{tabular}{lcccc}
\hline Group & \multicolumn{1}{c}{$\mathrm{T}_{0}$} & $\mathrm{~T}_{1}$ & $\mathrm{~T}_{3}$ & $\mathrm{~T}_{5}$ \\
\hline H group & $5.01 \pm 0.53$ & $5.21 \pm 0.53$ & $4.58 \pm 0.48$ & $5.11 \pm 0.45$ \\
C group & $5.08 \pm 0.51$ & $7.14 \pm 0.67^{\mathrm{a}, \mathrm{b}}$ & $7.61 \pm 0.69^{\mathrm{a}, \mathrm{b}}$ & $7.38 \pm 0.55^{\mathrm{a}, \mathrm{b}}$ \\
S group & $6.35 \pm 0.60^{\mathrm{a}, \mathrm{c}}$ & $8.73 \pm 0.72^{\mathrm{a}-\mathrm{c}}$ & $8.60 \pm 0.80^{\mathrm{a}-\mathrm{c}}$ & $8.54 \pm 0.78^{\mathrm{a}-\mathrm{c}}$ \\
\hline
\end{tabular}

Values are expressed as the mean \pm standard deviation. ${ }^{\mathrm{a}} \mathrm{P}<0.05$ compared to $\mathrm{H}$ group; ${ }^{\mathrm{b}} \mathrm{P}<0.05$ compared to $\mathrm{T}_{0}$ group; ${ }^{\mathrm{c}} \mathrm{P}<0.05$ compared to C group. H, sham group; C, CPB group; $\mathrm{S}$, sevoflurane-pre-conditioned group; $\mathrm{T}_{0}$, prior to $\mathrm{CPB}$; $\mathrm{T}_{1}, \mathrm{CPB}$ for $30 \mathrm{~min}$; $\mathrm{T}_{2}, \mathrm{CPB}$ for $1 \mathrm{~h}$; $\mathrm{T}_{3}, 1 \mathrm{~h}$ after 1-h CPB; $\mathrm{T}_{4}, 2 \mathrm{~h}$ after 1-h CPB; $\mathrm{T}_{5}, 3 \mathrm{~h}$ after 1-h CPB; CPB, cardiopulmonary bypass; TLR, Toll-like receptor.

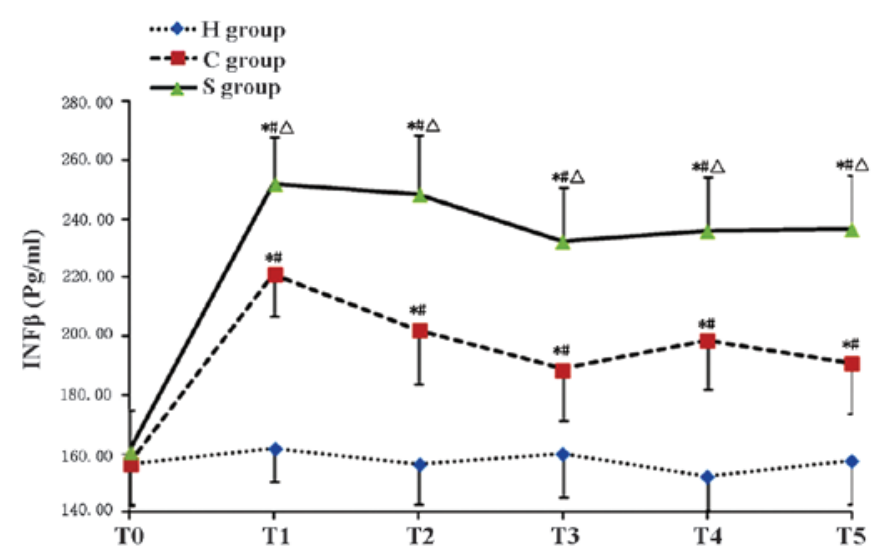

Figure 3. Concentration of IFN- $\beta$ in the experimental groups at various time-points. Values are expressed as the mean \pm standard deviation. ${ }^{*} \mathrm{P}<0.05$ compared with $\mathrm{T}_{0} ;{ }^{*} \mathrm{P}<0.05$ compared to $\mathrm{H}$ group; ${ }^{\Delta} \mathrm{P}<0.05$ compared with $\mathrm{C}$ group. $\mathrm{H}$, sham group; $\mathrm{C}, \mathrm{CPB}$ group; $\mathrm{S}$, sevoflurane-pre-conditioned group; $\mathrm{T}_{0}$, prior to $\mathrm{CPB} ; \mathrm{T}_{1}, \mathrm{CPB}$ for $30 \mathrm{~min} ; \mathrm{T}_{2}, \mathrm{CPB}$ for $1 \mathrm{~h} ; \mathrm{T}_{3}, 1 \mathrm{~h}$ after 1-h CPB; $\mathrm{T}_{4}, 2 \mathrm{~h}$ after 1 -h $\mathrm{CPB} ; \mathrm{T}_{5}, 3 \mathrm{~h}$ after 1 -h $\mathrm{CPB}$; CPB, cardiopulmonary bypass; IFN, interferon.

clinic at a concentration of 1 minimum alveolar concentration (MAC) $(27,28)$, and $2.4 \%$ sevoflurane is equivalent to $1 \mathrm{MAC}$ sevoflurane in rats. Hu etal (29) found that after pre-conditioning with $2.4 \%$ sevoflurane for $1 \mathrm{~h}$, ischemia-re-perfusion-induced brain injury was reduced. The rat middle cerebral artery occlusion model is used in current studies on brain injury, but sevoflurane has rarely been used in rat models of CPB. To better simulate clinical $\mathrm{CPB}$ and referring to preliminary studies by our group, $2.4 \%$ sevoflurane pre-conditioning of rats for $1 \mathrm{~h}$ was selected prior to establishing the CPB model.

$\mathrm{S} 100-\beta$ is a sensitive and neuron-specific protein, which is lowly expressed in normal brain tissue. Only when brain

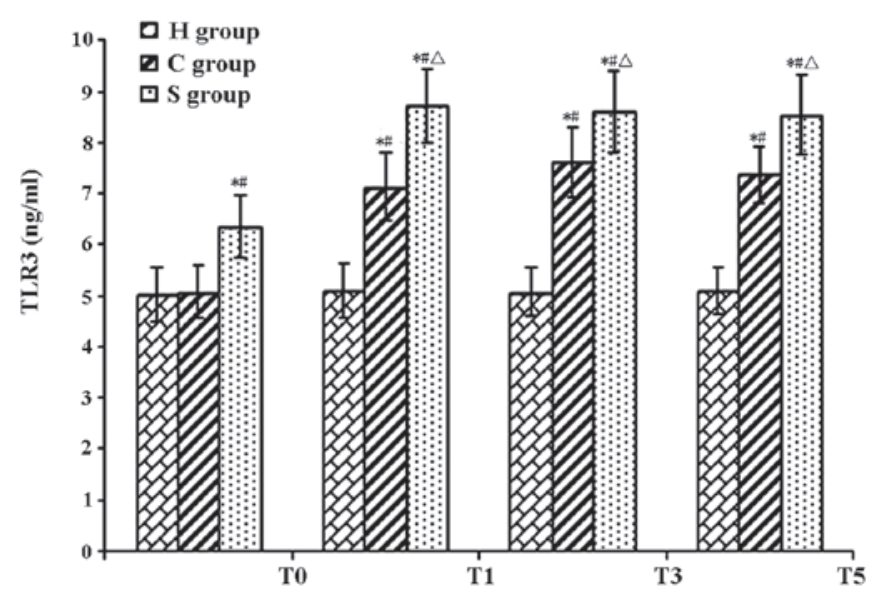

Figure 4. TLR3 protein levels in rat hippocampi in the experimental groups at various time-points. Values are expressed as the mean \pm standard deviation. ${ }^{\text {"}} \mathrm{P}<0.05$ compared with $\mathrm{T}_{0},{ }^{*} \mathrm{P}<0.05$ compared to $\mathrm{H}$ group; ${ }^{\Delta} \mathrm{P}<0.05$ compared with $\mathrm{C}$ group. $\mathrm{H}$, sham group; $\mathrm{C}, \mathrm{CPB}$ group; $\mathrm{S}$, sevoflurane-pre-conditioned group; $\mathrm{T}_{0}$, prior to $\mathrm{CPB} ; \mathrm{T}_{1}, \mathrm{CPB}$ for $30 \mathrm{~min} ; \mathrm{T}_{2}, \mathrm{CPB}$ for $1 \mathrm{~h} ; \mathrm{T}_{3}, 1 \mathrm{~h}$ after 1-h CPB; $\mathrm{T}_{4}, 2 \mathrm{~h}$ after $1-\mathrm{h} \mathrm{CPB} ; \mathrm{T}_{5}, 3 \mathrm{~h}$ after 1 -h CPB; CPB, cardiopulmonary bypass; TLR, Toll-like receptor.

tissue is damaged, cell and blood-brain barrier permeability increase, $\mathrm{S} 100-\beta$ is activated and then immediately expressed, released into the cerebrospinal fluid and passes through the blood-brain barrier; therefore, S100- $\beta$ levels in the peripheral blood effectively reflect the early extent of brain damage (30).

Accordingly, in studies on CPB-induced brain injury, S100- $\beta$ protein is utilized as a specific marker of early brain injury $(31,32)$. Singh et al (33) examined the effects of sevoflurane and isoflurane anesthesia as well as total intravenous anesthesia on patients undergoing coronary artery bypass grafting and found that the protein levels of S100- $\beta$ increased 
Table VI. TRIF expression levels in rat hippocampi in the experimental groups at various time-points.

\begin{tabular}{lcccc}
\hline Group & $\mathrm{T}_{0}$ & $\mathrm{~T}_{1}$ & $\mathrm{~T}_{3}$ & $\mathrm{~T}_{5}$ \\
\hline H group & $5.84 \pm 0.46$ & $5.66 \pm 0.48$ & $5.24 \pm 0.54$ & $5.76 \pm 0.55$ \\
C group & $6.04 \pm 0.11$ & $28.42 \pm 0.22^{\mathrm{a}, \mathrm{b}}$ & $24.59 \pm 0.34^{\mathrm{a}, \mathrm{b}}$ & $29.40 \pm 0.31^{\mathrm{a}, \mathrm{b}}$ \\
$\mathrm{S}$ group & $25.48 \pm 0.29^{\mathrm{a}, \mathrm{c}}$ & $36.49 \pm 0.33^{\mathrm{a}-\mathrm{c}}$ & $34.53 \pm 0.25^{\mathrm{a}-\mathrm{c}}$ & $35.53 \pm 0.27^{\mathrm{a}-\mathrm{c}}$ \\
\hline
\end{tabular}

Values are expressed as the mean \pm standard deviation. ${ }^{a} \mathrm{P}<0.05$ compared to $\mathrm{H}$ group; ${ }^{\mathrm{b}} \mathrm{P}<0.05$ compared to $\mathrm{T}_{0}$ group; ${ }^{\mathrm{c}} \mathrm{P}<0.05$ compared to $\mathrm{H}$ group. $\mathrm{H}$, sham group; $\mathrm{C}, \mathrm{CPB}$ group; $\mathrm{S}$, sevoflurane-pre-conditioned group; $\mathrm{T}_{0}$, prior to $\mathrm{CPB} ; \mathrm{T}_{1}, \mathrm{CPB}$ for $30 \mathrm{~min} ; \mathrm{T}_{2}, \mathrm{CPB}$ for $1 \mathrm{~h} ; \mathrm{T}_{3}, 1 \mathrm{~h}$ after 1-h CPB; $\mathrm{T}_{4}, 2 \mathrm{~h}$ after $1-\mathrm{h} \mathrm{CPB} ; \mathrm{T}_{5}, 3 \mathrm{~h}$ after 1 - $\mathrm{h} \mathrm{CPB} ; \mathrm{CPB}$, cardiopulmonary bypass; TRIF, TIR-domain-containing adapter-inducing interferon- $\beta$.

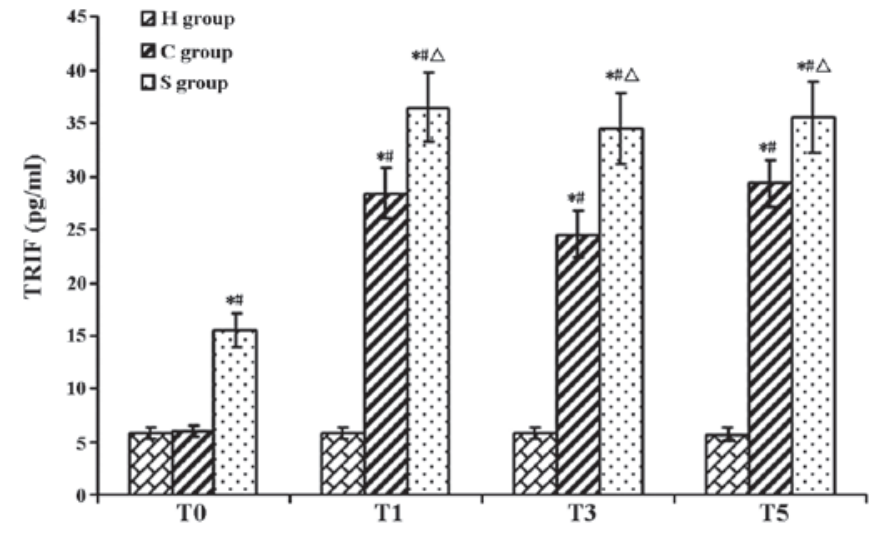

Figure 5. TRIF protein levels in rat hippocampi in the experimental groups at various time-points. Values are expressed as the mean \pm standard deviation. ${ }^{\#} \mathrm{P}<0.05$ compared with $\mathrm{T}_{0} ;{ }^{*} \mathrm{P}<0.05$ compared to $\mathrm{H}$ group; ${ }^{\Delta} \mathrm{P}<0.05$ compared with $\mathrm{H}$ group. $\mathrm{H}$, sham group; $\mathrm{C}, \mathrm{CPB}$ group; $\mathrm{S}$, sevoflurane-pre-conditioned group; $\mathrm{T}_{0}$, prior to $\mathrm{CPB} ; \mathrm{T}_{1}, \mathrm{CPB}$ for $30 \mathrm{~min} ; \mathrm{T}_{2}, \mathrm{CPB}$ for $1 \mathrm{~h} ; \mathrm{T}_{3}, 1 \mathrm{~h}$ after 1-h CPB; $\mathrm{T}_{4}, 2 \mathrm{~h}$ after 1 - $\mathrm{h} \mathrm{CPB} ; \mathrm{T}_{5}, 3 \mathrm{~h}$ after 1-h CPB; CPB, cardiopulmonary bypass; TRIF, TIR-domain-containing adapter-inducing interferon- $\beta$.

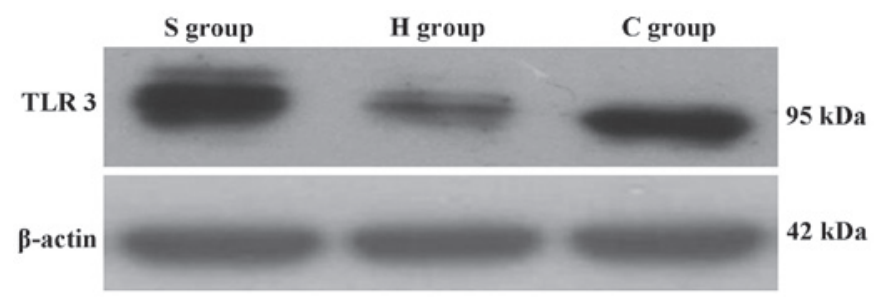

Figure 6. Western blot analysis of TLR3 expression levels in rat hippocampi. $\mathrm{H}$, sham group; $\mathrm{C}, \mathrm{CPB}$ group; $\mathrm{S}$, sevoflurane-pre-conditioned group at $\mathrm{T}_{5}$.

rapidly after $\mathrm{CPB}$. Of note, sevoflurane was able to reduce the serum levels of $\mathrm{S} 100-\beta$ in the patients. In the present study, the levels of S100- $\beta$ were close to normal prior to CPB. During the CPB, S100- $\beta$ levels in the $\mathrm{H}$ group remained low, indicating that simple puncture did not cause any significant brain damage. Compared with that in the $\mathrm{H}$ group, the $\mathrm{S} 100-\beta$ concentration in the $\mathrm{C}$ and $\mathrm{S}$ groups significantly increased during $\mathrm{CPB}$ and remained at elevated levels after CPB, indicating that $\mathrm{CPB}$ caused brain injury in rats.

In the present study, TUNEL staining was performed to detect cell apoptosis. Compared to that in the $\mathrm{H}$ group, cell apoptosis was significantly increased in the $\mathrm{C}$ and $\mathrm{S}$ groups. Of note, sevoflurane pre-conditioning significantly reduced S100- $\beta$ levels and the number of apoptotic hippocampal neurons

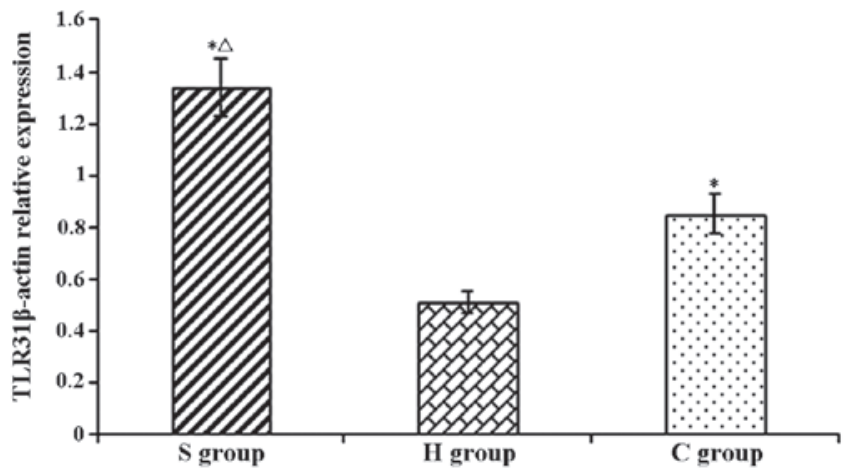

Figure 7. Relative expression levels of TLR3 in rat hippocampi determined by western blot analysis. Values are expressed as the mean \pm standard deviation. ${ }^{*} \mathrm{P}<0.05$ compared with $\mathrm{H}$ group; ${ }^{\Delta} \mathrm{P}<0.05$ compared with $\mathrm{C}$ group. $\mathrm{H}$, sham group; C, CPB group; S, sevoflurane-pre-conditioned group.

at each time-point compared with those in the $\mathrm{C}$ group. These results suggested that $\mathrm{CPB}$ caused brain damage and apoptosis of hippocampal neurons, while sevoflurane pre-conditioning had a protective effect as indicated by decreased levels of serum S100- $\beta$ and apoptotic hippocampal neurons.

Sevoflurane pre-conditioning alleviates brain damage through reducing the $C P B$-induced inflammatory response. Various factors during CPB can cause the release of a large number of lymphocytes and other pro-inflammatory cytokines as well as the development of systemic inflammatory response syndrome (34). These factors include non-physiological perfusion or reduced local oxygen supply, which can be caused by insufficient blood supply, resulting in great damage to the brain. Recent studies have shown that inflammation is an important cause of cognitive dysfunction after CPB $(35,36)$; therefore, the focus of the present study was on how to positively and effectively reduce inflammation-induced damage during CPB.

IPC can enhance the brain's tolerance to traumatic effects of ischemia and hypoxia through pre-experimental cerebral ischemia (37). The inflammatory reaction is an important cause of brain damage and inflammation may synergistically aggravate hypoxic-ischemic brain damage (38). A study showed that prevention of inflammation can enhance the protective effect of IPC against cerebral ischemia, as IPC alleviates the extent of ischemia by decreasing the expression of pro-inflammatory genes and reducing neutrophil and macrophage infiltration in the ischemic area of infiltration (4). 

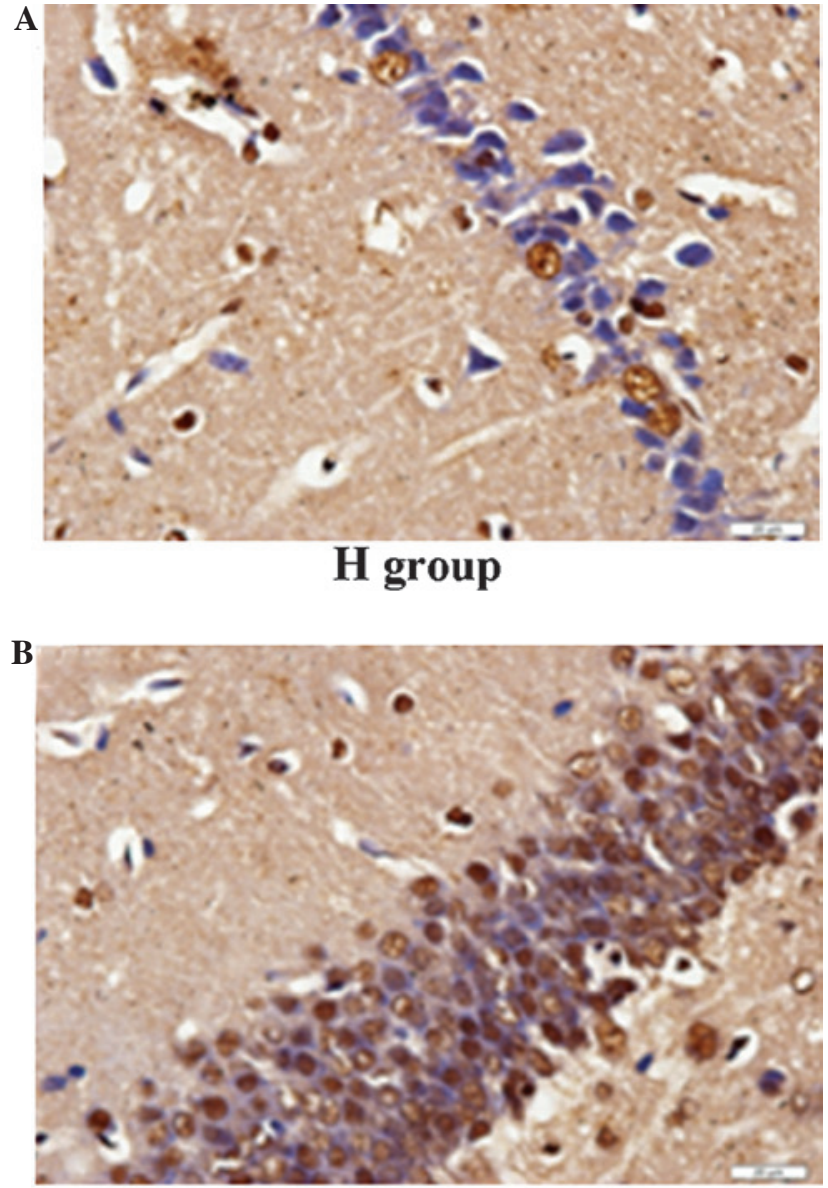

C group

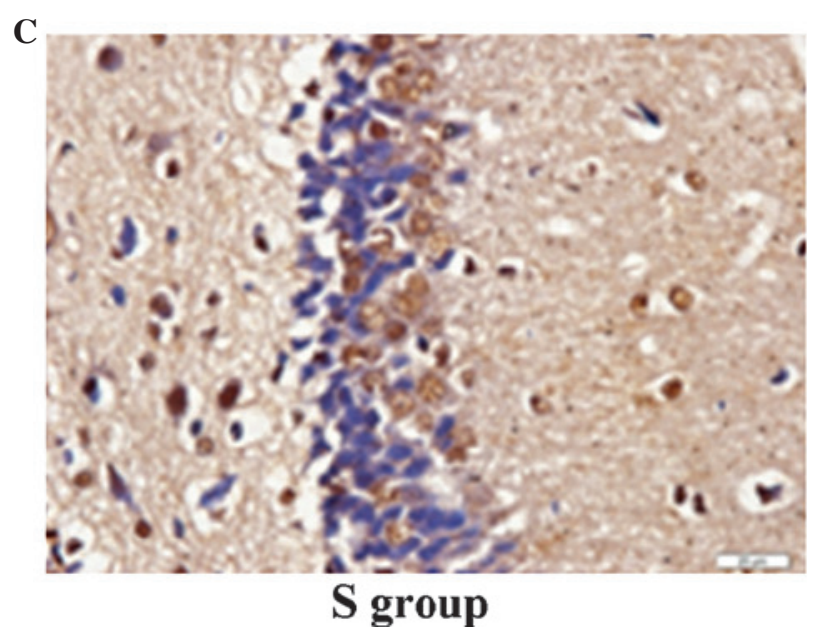

Figure 8. Apoptosis of hippocampal neurons as indicated by terminal deoxynucleotidyl transferase dUTP nick end labeling in (A) $\mathrm{H}$ group, (B) $\mathrm{C}$ group and (C) S group (magnification, $\mathrm{x} 400$ ). $\mathrm{H}$, sham group; $\mathrm{C}, \mathrm{CPB}$ group; $\mathrm{S}$, sevoflurane-pre-conditioned group.

In a study on patients with coronary artery bypass and valve replacement, Ramlawi et al (39) found that in the early post-operative stage, serum levels of IL-1 are significantly increased in patients with cognitive decline, and that the amount of cognitive decline is IL-1 concentration-dependent.

Ashraf et al (40) found that during CPB, S100- $\beta$ protein levels positively correlated with IL-6 expression levels, while expression of IL- 6 promoted the protein levels of S100- $\beta$ as

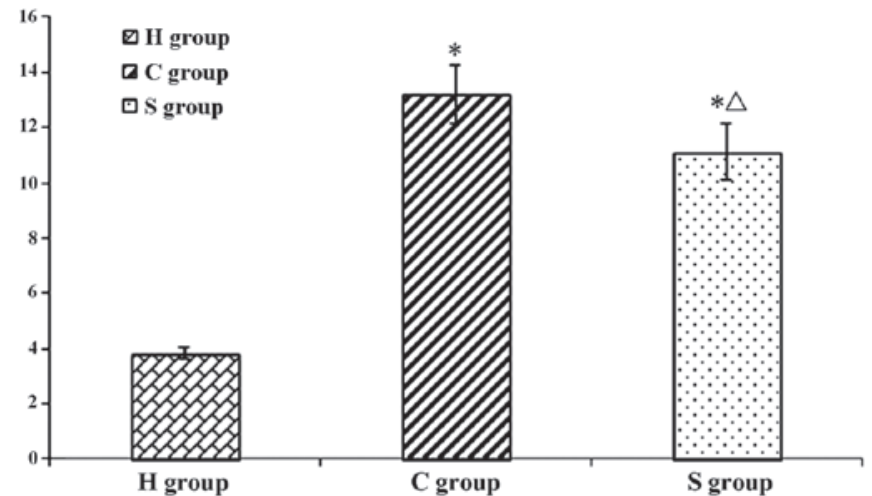

Figure 9. Integrated Optical Density Average value of positive hippocampal neuronal cells in each group. Values are expressed as the mean \pm standard deviation. ${ }^{*} \mathrm{P}<0.05$ compared with $\mathrm{H}$ group; ${ }^{\Delta} \mathrm{P}<0.05$ compared with $\mathrm{C}$ group. $\mathrm{H}$, sham group; $\mathrm{C}, \mathrm{CPB}$ group; $\mathrm{S}$, sevoflurane-pre-conditioned group.

well as the participation of inflammatory mediators and exacerbated brain damage.

Vila et al (41) showed that IL-6 is closely associated with the area of acute cerebral infarction. The serum concentration of IL-6 was in parallel with the size of the cerebral infarction area, an independent risk factor of brain damage. The possible mechanisms is the promotion of aggregation and adhesion of inflammatory cells, partial infarction of brain tissue, activation of matrix metalloproteinases, destruction of the blood-brain barrier, stimulation of platelet activity, promotion of fibrinogen production and reduction of cerebral perfusion (42-45).

Bedirli et al (46) found that sevoflurane pre-conditioning reduced ischemia-reperfusion-induced levels of inflammatory cytokines (TNF- $\alpha$ and IL-1 $\beta$ ), thus reducing the inflammatory reaction caused by brain damage and thereby protecting the brain.

The present study found that the concentration of IL-6 in the $\mathrm{CPB}$ group was significantly higher than that in Group $\mathrm{H}$ during CPB and largely remained at a high level, indicating that inflammation occurs during CPB. Compared with those in the $\mathrm{C}$ group, the levels of IL- 6 in the $\mathrm{S}$ group were significantly lower at each time-point. These results suggested that sevoflurane pre-conditioning alleviated the inflammatory response during CPB and exerted a protective effect on the brain through inhibiting the expression of the inflammatory cytokine IL-6.

The TLR3 signaling pathway is involved in the protective effect of sevoflurane on the brain during CPB. Previous studies found that pre-excited TLRs suppress brain inflammation and thus alleviate the effects of brain injury $(7,8)$. TLRs are innate immunity receptors widely expressed in the central nervous system, and TLR1-9 are expressed in primary cultured human microglia cells. The TLR family is involved in two signaling pathways: The MyD88-dependent pathway and the TRIF-dependent pathway. TLRs (except TLR3) increase the synthesis and release of pro-inflammatory cytokines by combining with the downstream protein MyD88 via the MyD88-dependent pathway. In the TRIF-dependent pathway, TLR3 and TLR4 are involved in type I interferon signaling to increase the expression of anti-inflammatory cytokines such as IFN- $\beta$. 
The TLR3 pathway is the only solely TRIF-dependent pathway amongst all TLR pathways. TLR3 is expressed throughout the central nervous system and is highly expressed in astrocytes; TLR3 is particularly sensitive to cell damage (47). TLRs are involved in the brain damage response to ischemia caused by inflammation through which they are activated to alleviate inflammation, and are pre-stimulated to provide a powerful neuroprotective effect (48). Pan et al (11) stimulated the expression of TLR3 by using the TLR3 agonist polyinosinic polycytidylic acid, which inhibited the release of pro-inflammatory cytokines as well as the expression of nuclear factor $(\mathrm{NF})-\kappa \mathrm{B}$ and IL-6, and mitigated nerve cell damage.

In the present study, the TLR3 levels in the C group were significantly increased with the onset of CPB as compared with those in the $\mathrm{H}$ group, indicating $\mathrm{CPB}$ activated the expression $\mathrm{n}$ of TLR3 expression. Compared to those in the CPB group, the expression levels of TLR3 were significantly elevated in the $\mathrm{S}$ group even at $\mathrm{T}_{0}$ prior to $\mathrm{CPB}$, which may be due to sevoflurane-induced pre-activated expression of the TLR3. During and after CPB, the levels of TLR3 in the S group were significantly higher than those in the $\mathrm{C}$ group, indicating that sevoflurane pre-conditioning up-regulated the expression of TLR3, thereby exerting a protective effect on the brain and reducing brain damage in rats caused by $\mathrm{CPB}$.

TLR3 signaling pathways associated with the neuroprotective effect of sevoflurane pre-conditioning. When the body is subjected to external pathogen invasion, TLR3 combines with the pathogen through the TRIF-dependent pathway, activating the expression of downstream anti-inflammatory cytokines, including IFN- $\beta$, inhibiting the expression of pro-inflammatory cytokines, such as IL-6, and alleviating inflammation. TLR3 signaling is transduced exclusively through the TRIF pathway; thus, activating the expression of TLR3 may help to restore the balance between pro-inflammatory and anti-inflammatory cytokines following CPB, resulting in neuroprotection.

Previous studies suggested that pre-treatment with lipopolysaccharide (LPS) or de-regulation of TRIF expression through IPC, ultimately increasing the release of anti-inflammatory cytokines, inhibits the release of pro-inflammatory cytokines mediated by $\mathrm{NF}-\kappa \mathrm{B}$, thus protecting the brain $(6,8)$ Nhu et al (49) found that LPS pre-treatment can upregulate TLR3 expression, thereby increasing the expression of downstream proteins of the TRIF pathway.

In the present study, it was observed that TLR3, TRIF and IFN- $\beta$ expression levels were elevated in the $\mathrm{C}$ group, showing the same tendency as S100- $\beta$ protein. After sevoflurane preconditioning, the expression levels of TLR3 and TRIF, IFN- $\beta$ were further increased, while the expression of the pro-inflammatory cytokine IL- 6 and the brain damage marker S100- $\beta$ was decreased. The TLR3 signaling pathway may be pre-activated by sevoflurane, increasing the expression levels of TLR3 and its downstream signaling molecule TRIF prior to as well as during CPB to exert their protective effects against brain damage.

The present study generated a rat model of CPB and observed that sevoflurane pre-conditioning had a protective role on the brain to reduce $\mathrm{CPB}$-induced damage. This protective role may be associated with the TLR3 signaling pathway, providing a novel target to prevent brain damage and improve the outcomes of clinical CPB. The findings of the present study can be concluded as follows: i) Sevoflurane pre-treatment has a protective effect against CPB-induced brain injury; ii) sevoflurane pre-treatment alleviates cerebral injury caused by a CPB-induced inflammatory reaction, through affecting the TLR3 signaling pathway; and iii) TLR3 signaling pathways involved in the neuroprotective effects of sevoflurane include the pre-activation of TLR3, up-regulation of the downstream TRIF, inhibition of the expression of pro-inflammatory cytokines IL-6 and upregulation of the anti-inflammatory factor IFN- $\beta$.

Further in-depth studies are required to explore the downstream mechanisms of TLR3-associated brain protection by sevoflurane. In addition, it should be attempted to discover the role of the each TLR and their cross-protective mechanisms in order to ultimately provide a theoretical support for the effects of cardiovascular surgeries on the brain as well as strategies to prevent brain damage.

\section{Acknowledgements}

The present study was supported by the Liaoning Natural Science Foundation (grant no. 20102244).

\section{References}

1. Lombard FW and Mathew JP: Neurocognitive dysfunction following cardiac surgery. Semin Cardiothorac Vasc Anesth 14: 102-110, 2010.

2. McKhann GM, Grega MA, Borowicz LM Jr, Baumgartner WA and Selnes OA: Stroke and encephalopathy after cardiac surgery: An update. Stroke 37: 562-571, 2006.

3. Mei B: Study of brain injury and brain protection during cardiopulmonary bypass progress. Zhong Guo Ti Wai Xun Huan Za Zhi 8: 125-127, 2010 (In Chinese).

4. Bowen KK, Naylor $M$ and Vemuganti R: Prevention of inflammation is a mechanism of preconditioning-induced neuroprotection against focal cerebral ischemia. Neurochem Int 49: 127-135, 2006.

5. Pradillo JM, Fernández-López D, García-Yébenes I, Sobrado M, Hurtado O, Moro MA and Lizasoain I: Toll-like receptor 4 is involved in neuroprotection afforded by ischemic preconditioning. J Neurochem 109: 287-294, 2009

6. Broad A, Kirby JA and Jones DE; Applied Immunology and Transplantation Research Group: Toll-like receptor interactions: Tolerance of MyD88-dependent cytokines but enhancement of MyD88-independent interferon-beta production. Immunology 120: 103-111, 2007

7. Marsh B, Stevens SL, Packard AE, Gopalan B, Hunter B, Leung PY, Harrington CA and Stenzel-Poore MP: Systemic lipopolysaccharide protects the brain from ischemic injury by reprogramming the response of the brain to stroke: A critical role for IRF3. J Neurosci 29: 9839-9849, 2009.

8. Marsh BJ and Stenzel-Poore MP: Toll-like receptors: Novel pharmacological targets for the treatment of neurological diseases. Curr Opin Pharmacol 8: 8-13, 2008.

9. De Miranda J, Yaddanapudi K, Hornig M, Villar G, Serge R and Lipkin WI: Induction of Toll-like receptor 3-mediated immunity during gestation inhibits cortical neurogenesis and causes behavioral disturbances. MBio 1: e00176-10, 2010.

10. Bsibsi M, Persoon-Deen C, Verwer RW, Meeuwsen S, Ravid R and Van Noort JM: Toll-like receptor 3 on adult human astrocytes triggers production of neuroprotective mediators. Glia 53: 688-695, 2006.

11. Pan LN,Zhu W,Li C, Xu XL, Guo LJ and Lu Q: Toll-like receptor 3 agonist Poly I:C protects against simulated cerebral ischemia in vitro and in vivo. Acta Pharmacol Sin 33: 1246-1253, 2012.

12. Djaiani G, Fedorko L, Borger MA, Green R, Carroll J, Marcon M and Karski J: Continuous-flow cell saver reduces cognitive decline in elderly patients after coronary bypass surgery. Circulation 116: 1888-1895, 2007. 
13. Yan YG, Wang DJ, Wu Z, Li QZ and Zhou Q: Relevant factors for severe neurological complications after coronary artery bypass graft. Zhong Guo Zu Zhi Gong Cheng Yan Jiu 14: 1174-1178, 2010 (In Chinese)

14. Anttila V, Hagino I, Iwata Y, Mettler BA,Lidov HG,Zurakowski D and Jonas RA: Aprotinin improves cerebral protection: Evidence from a survival porcine model. J Thorac Cardiovasc Surg 132: 948-953, 2006.

15. Elefteriades JA: What is the best method for brain protection in surgery of the aortic arch? Straight DHCA. Cardiol Clin 28 381-387, 2010

16. Nelson DP, Andropoulos DB and Fraser CD Jr: Perioperative neuroprotective strategies. Semin Thorac Cardiovasc Surg Pediatr Card Surg Annu 11: 49-56, 2008.

17. Head BP and Patel P: Anesthetics and brain protection. Curr Opin Anesthesiol 20: 395-399, 2007.

18. Xiong L, Zheng Y, Wu M, Hou L, Zhu Z, Zhang X and Lu Z: Preconditioning with isoflurane produces dose-dependent neuroprotection via activation of adenosine triphosphate-regulated potassium channels after focal cerebral ischemia in rats. Anesth Analg 96: 233-237, 2003.

19. Kitagawa K, Matsumoto M, Tagaya M, Hata R, Ueda H, Niinobe M, Handa N, Fukunaga R, Kimura K and Mikoshiba K: 'Ischemic tolerance' phenomenon found in the brain. Brain Res 528: 21-24, 1990

20. Yang Q, Dong H, Deng J, Wang Q, Ye R, Li X, Hu S, Dong H and Xiong L: Sevoflurane preconditioning induces neuroprotection through reactive oxygen species-mediated up-regulation of antioxidant enzymes in rats. Anesth Analg 112: 931-937, 2011.

21. Wang J,Lei B,Popp S, Meng F, Cottrell JEand Kass IS: Sevoflurane immediate preconditioning alters hypoxic membrane potential changes in rat hippocampal slices and improves recovery of CA1 pyramidal cells after hypoxia and global cerebral ischemia. Neuroscience 145: 1097-1107, 2007.

22. Payne RS, Akca O, Roewer N, Schurr A and Kehl F: Sevoflurane-induced preconditioning protects against cerebral ischemic neuronal damage in rats. Brain Res 1034: 147-152, 2005.

23. Park HP, Jeong EJ, Kim MH, Hwang JW, Lim YJ, Min SW, Kim CS and Jeon YT: Effects of sevoflurane on neuronal cell damage after severe cerebral ischemia in rats. Korean J Anesthesiol 61: 327-331, 2011.

24. Dabrowski W, Rzecki Z, Czajkowski M, Pilat J, Wacinski P, Kotlinska E, Sztanke M, Sztanke K, Stazka K and Pasternak K: Volatile anesthetics reduce biochemical markers of brain injury and brain magnesium disorders in patients undergoing coronary artery bypass graft surgery. J Cardiothorac Vasc Anesth 26 395-402, 2012

25. Wang H, Lu S, Yu Q, Liang W, Gao H, Li P, Gan Y, Chen J and Gao Y: Sevoflurane preconditioning confers neuroprotection via anti-inflammatory effect. Front Biosci (Elite Ed) 3: 604-615, 2011.

26. Song DD, Gao GJ, Sun YJ, Zhang TZ, Zhou J, Zhang Y and Yao Q: Rats without blood prefilled established model of cardiopulmonary bypass with cardiac arrest. Zhong Guo Ti Wai Xun Huan Za Zhi 4: 232-235, 2009 (In Chinese).

27. Obal D, Preckel B, Scharbatke H, Müllenheim J, Höterkes F, Thämer V and Schlack W: One MAC of sevoflurane provides protection against reperfusion injury in the rat heart in vivo. Br J Anaesth 87: 905-911, 2001.

28. Payne RS, Akca O, Roewer N, Schurr A and Kehl F: Sevoflurane-induced preconditioning protects against cerebral ischemic neuronal damage in rats. Brain Res 1034: 147-152, 2005.

29. Hu X, Zhang Y, Li W, Liu J and Li Y: Preconditioning with sevoflurane ameliorates spatial learning and memory deficit after focal cerebral ischemia-reperfusion in rats. Int $\mathbf{J}$ Dev Neurosci 31: 328-333, 2013.

30. Groom RC, Quinn RD, Lennon P, Welch J, Kramer RS, Ross CS, Beaulieu PA, Brown JR, Malenka DJ, O'Connor GT, et al: Microemboli from cardiopulmonary bypass are associated with a serum marker of brain injury. J Extra Corpor Technol 42 : 40-44, 2010.

31. Herrmann M, Ebert AD, Galazky I, Wunderlich MT, Kunz WS and Huth C: Neurobehavioral outcome prediction after cardiac surgery role of neurobiochemical markers of damage to neuronal and glial brain tissue. Stroke 31: 645-650, 2000
32. Aly WW, Abdul-Rahman SA, El Said SMS, et al: S100B and delirium in the geriatric acute care setting. Adv Aging Res 3: $1-5,2014$.

33. Singh SP, Kapoor PM, Chowdhury U and Kiran U: Comparison of S100 $\beta$ levels and their correlation with hemodynamic indices in patients undergoing coronary artery bypass grafting with three different anesthetic techniques. Ann Card Anaesth 14: 197-202, 2011.

34. Nikolakopoulou Z, Smith M, Hector LR, et al: S100A12 as a biomarker for neutrophil mediated inflammation in patients undergoing cardiac surgery necessitating cardiopulmonary bypass. Thorax 68: 141-141, 2013.

35. Song J, Park J, Kim JY, Kim JD, Kang WS, Muhammad HB, Kwon MY, Kim SH, Yoon TG, Kim TY and Chung JW: Effect of ulinastatin on perioperative function and systemic inflammatory reaction during cardiac suregry: A randomized double-blinded study. Korean J Anesthesiol 64: 334-340, 2013.

36. Li W, Wu X, Yan F, Liu J, Tang Y, Ma K and Li S: Effects of pulmonary artery perfusion with urinary trypsin inhibitor as a lung protective strategy under hypothermic low-flow cardiopulmonary bypass in an infant piglet model. Perfusion 29: 434-442, 2014

37. Liu XQ, Sheng R and Qin ZH: The neuroprotective mechanism of brain ischemic preconditioning. Acta Pharmacol Sin 30: 1071-1080, 2009.

38. Lakhan SE, Kirchgessner A and Hofer M: Inflammatory mechanisms in ischemic stroke: Therapeutic approaches. J Transl Med 7: 97, 2009

39. Ramlawi B, Rudolph JL, Mieno S, Feng J, Boodhwani M, Khabbaz K, Levkoff SE, Marcantonio ER, Bianchi $\mathrm{C}$ and Sellke FW: C-Reactive protein and inflammatory response associated to neurocognitive decline following cardiac surgery. Surgery 140: 221-226, 2006

40. Ashraf S, Bhattacharya K, Tian Y and Watterson K: Cytokine and S100B levels in paediatric patients undergoing corrective cardiac surgery with or without total circulatory arrest. Eur J Cardiothorac Surg 16: 32-37, 1999.

41. Vila N, Castillo J, Dávalos A and Chamorro A: Proinflammatory cytokines and early neurological worsening in ischemic stroke. Stroke 31: 2325-2329, 2000

42. Selzner N, Selzner M, Odermatt B, Tian Y, Van Rooijen N and Clavien PA: ICAM-1 triggers liver regeneration through leukocyte recruitment and Kupffer cell-dependent release of TNF-alpha/IL-6 in mice. Gastroenterology 124: 692-700, 2003.

43. Liu ZM, Yang QD, Liu YH, Huang XS and Zhang N: Serum IL-6 in patients with cerebral infarction and SICAM-1 and its clinical significance. Zhong Nan Da Xue Xue Bao Yi Xue Ban 29: 326-329, 2004 (In Chinese).

44. Reinsfelt B, Ricksten SE, Zetterberg H, Blennow K, Fredén-Lindqvist $\mathrm{J}$ and Westerlind A: Cerebrospinal fluid markers of brain injury, inflammation and blood-brain barrier dysfunction in cardiac surgery. Ann Thorac Surg 94: 549-555, 2012.

45. Lee SH, Kim BJ, Kim YB, Chung PW, Moon HS, Suh BC, Yoon WT, Jin DK, Park YS, Lee YT and Park K Y: IL-1ß induction and IL-6 suppression are associated with aggravated neuronal damage in a lipopolysaccharide-pretreated kainic acid-induced rat pup seizure model. Neuroimmunomodulation 19: 319-325, 2012.

46. Bedirli N, Bagriacik EU, Emmez H, Yilmaz G, Unal Y and Ozkose Z: Sevoflurane and isoflurane preconditioning provides neuroprotection by inhibition of apoptosis-related mRNA expression in a rat model of focal cerebral ischemia. $J$ Neurosurg Anesthesiol 24: 336-344, 2012

47. Barreto G, White RE, Ouyang Y, Xu L and Giffard RG: Astrocytes: Targets for neuroprotection in stroke. Cent Nerv Syst Agents Med Chem 11: 164-173, 2011.

48. Rosenzweig HL, Lessov NS, Henshall DC, Minami M, Simon RP and Stenzel-Poore MP: Endotoxin preconditioning prevents cellular inflammatory response during ischemic neuroprotection in mice. Stroke 35: 2576-2581, 2004.

49. Nhu QM, Cuesta N and Vogel SN: Transcriptional regulation of lipopolysaccharide (LPS) -induced toll-like receptor (TLR) expression in murine macrophages: Role of interferon regulatory factors 1 (IRF-1) and 2 (IRF-2). J Endotoxin Res 12: 285-295, 2006. 